\title{
Leadership, Collective Action in Developing Natural Farming: A Case Study at Wufeng District, Taichung City in Taiwan
}

\author{
Aiching Yen \\ Department of Land Economics, College of Social Sciences, National Chengchi University, Taipei City, Taiwan
}

Email address:

irene1@mail2.nccu.tw

To cite this article:

Aiching Yen. Leadership, Collective Action in Developing Natural Farming: A Case Study at Wufeng District, Taichung City in Taiwan. Science Innovation. Vol. 6, No. 3, 2018, pp. 134-142. doi: 10.11648/j.si.20180603.14

Received: March 1, 2018; Accepted: March 23, 2018; Published: June 22, 2018

\begin{abstract}
There is different character in each rural region which has its own set of opportunities and constraints. Due to the constraints, local leaders should mobilize actors together to build an understanding of how appropriately to find and use the resources. Drawing upon the local leadership and collective action literatures and based on evidence, this paper tries to explore the leadership of places through an examination of the experience of a Wufeng District Famers' Association in Taichung City, Taiwan, whose purposes are safeguarding farmers' rights and interests, enhancing farmers' knowledge and skills, boosting the modernization of agriculture, increasing crop yields, improving farmers' livelihood and developing rural economy. Whether these purposes can be achieved, the leadership of the director-general is the key to the outcome. In view of the importance of the healthy food supply, the director-general of the Wufeng Famers' Association mobilizes the farmers to transfer from conventional farming to natural farming. In order to understand the role of leadership in collective action of promoting natural farming, this study takes qualitative research method and proposes three important driving forces that have contributed to the transformation of natural farming: the farmers' association shapes the vision and plans the incentive mechanism, the agricultural experimentation station provides the cultivation techniques, and the successful mobilization of leaders of the production and marketing group. Some of research findings are:1. the role of leaders serves as essential 'managers' and 'intermediaries' to initiate and sustain collective action, and 2. the leaders seek for opportunities for resolving the problems facing sustainable development and tackling the challenges of collaborative and uncertain issues, 3 . through the promoting of the leaders, the farmland area of natural farming is expanding rather quickly and turn the products of natural farming into high quality wine. The collective action seems successful; nevertheless, the leaders are still needed to cope with challenges from external environment. This paper hopes to share the experiences in Taiwan rural organization, deepen the theoretical dialogue, and extend the network for further social practices.
\end{abstract}

Keywords: Collective Action, Leadership, Sustainable Development, Natural Farming, Taiwan

\section{發展自然農業的領導能力與集體行動：台灣台中市霧峰區的個案 研究}

\author{
顏愛靜 \\ 社會科學學院地政學系, 國立政治大學, 台北市, 台灣
}

邮箱:

irene1@mail2.nccu.tw 


\begin{abstract}
摘要: 每個農村地區都有不同的特點, 各有其機會和制約因素。由於受到限制, 地方領導人理應動員參與者, 以便共 同了解如何恰如其分地發現和使用資源。本文借鑒地方領導和集體行動文獻，以質性證據為基礎，藉由台灣中部霧峰 區農會的經驗的考察, 以探討地方領導人的地位。而農會設立之目的在於增強農民的知識和技能, 提高農作物產量, 改善農民生計和發展農村經濟; 這些目的能否達成, 總幹事的領導力則是成敗的關鍵所在。有鑑於健康農產品供應的 重要性, 霧峰農會總幹事動員農民由慣行農業轉作自然農業。為理解領導在推動自然農業中集體行動的作用, 本研究 採用質性研究方法, 分析促成農法轉型的三個重要驅動因素：農會塑造願景並規劃誘因機制、農試所提供栽培技術、 產銷班領導成功動員。一些研究成果是：1.領導者的角色是啟動和維持集體行動的必要「經理人」與「中介人」;2.領 導者尋求機會解決可持續發展面臨的問題, 應對合作和不確定性的挑戰; 3.領導者推動自然農業的耕地面積正在迅速擴 大, 將自然農業的產品轉化為優質清酒。不過, 集體行動似乎成功了, 領導人仍然需要應付來自外部環境的挑戰。本 文希望分享台灣農村組織的經驗，深化理論對話，拓展網絡，進而達成社會實踐。
\end{abstract}

关键词：集體行動，領導力，可持續發展，自然農業，台灣

\section{1. 引言}

近年來，面對食物安全和全球化食物供應系統的問題 層出不窮, 促使人們反思如何供應健康可靠的糧食, 從而 無毒、自然農業或是有機農業再度受到重視。雖然，有機 農業被視為因應氣候變遷，具有環境、經濟、社會效益的 智慧型農業，然因有機農業的推展，受到生產地理條件、 田間栽培管理、須經嚴格驗證等規定的限制，推廣相對困 難。因而, 朝向無毒或友善的自然農業發展, 或是朝向可 持續發展的第一步。儘管各方對自然農業的界定各有不同, 但不用化學性投入, 不除雜草或僅局部除草, 以微生物增 進土壤的營養物質, 或是通常的見解。不過, 在一般農民 多採慣行農業的情況下, 要轉向自然農業並不容易。

位居台灣中部的台中市霧峰區, 有一群體認慣行農業 對生態環境為害的人們, 意想推動轉型為自然農業。但是, 農業轉型不能只靠個人, 還須展開集體行動, 使耕種坻塊 相連形成完整地區，農民一起協同調整，才有實現理想的 可能。霧峰農會總幹事是位關鍵的領導人, 於1995年進入 農會服務, 於2001年擔任現職, 推動良質益全香米栽種, 近年受到台灣糧食安全、環保議題影響, 乃開始推動「五 甲地」自然農法, 由農會出資補助農民, 盼栽種出不用農 藥、沒有化肥的無毒米, 以復育生態環境。然要農民落實 執行, 還須有農業社區領導人展開動員。在本案例中, 其 實是一種由下而上的自主治理行動, 政府資源並未進入, 全靠農會自行規劃誘因機制, 鼓勵農民加入變革的行列。 這樣的領導人可視為制度或社會企業家，藉由提供契作優 惠價格以促進制度變遷的集體行動。

本文的撰寫目的, 在於藉由理論基礎以探討影響個案 地區自然農業推展的關鍵因素, 並闆明領導階層的創業精 神如何在集體行動中發揮重要的作用。全文的進展順序為: 首先引介相關文獻綜述, 特別是著重領導人和集體行動、 創業精神及其關係的文獻。其次, 說明研究方法。接著, 簡介研究個案的社會經濟背景。再次, 藉由訪談結果分析 領導人與集體行動之關聯性, 並指出領導人在集體行動的 作用, 最後則簡要歸納研究結論。

\section{2. 文獻綜述}

本文所謂的自然農業雖與相關文獻所稱或做法有所 差別, 但基本精神或原則類同, 仍值得予以引介。另就一 般概念言，集體行動之目的在於實現團體的共同目標。集 體行動理論主要側重於理解團體成員之間的相互作用, 制 定規則以及監督遵守和解決投訴的機制。至於集體行動如 何出現和關鍵領導人所扮演的角色則較少受到關注, 故本 文關於領導人和創業精神的文獻有助於填補這一缺口。茲 就重要文獻, 分別扼要探討如次。

\section{1. 自然農業}

健康的土壤是可持續農業經營的基礎。而農業實作的 差異, 主要在於土壤投入和作物保護措施有所不同。在慣 行的化學農業實作中, 濫用化學肥料和殺蟲劑將破壞有益 土壤的微生物群落, 會改變土壤的性質, 也會導致作物生 產成本高昂。一旦土壤遭受重金屬的污染物, 可能大量進 入食物鏈, 從而對人體健康有不利的影響。而無機的化學 肥料和農藥的大量使用, 亦會導致土壤、地表和地下水有 害化學物質和重金屬的積累 [1-2]。相反地, 自然農業的本 質則是盡量減少對農田的外部投入, 並培育土壤肥力, 藉 由有益土壤微生物的繁殖而使壤質營養更為豐富[3]。

所謂自然農業, 是指一種與自然界合作生產健康食品, 可保持自身健康, 也維護土地健康的經營方式。其哲理在 於, 自然界的一切事物都是有用的, 並在生活網絡中產生 一定的作用。這種農耕的進程也被稱為「無所事事」, 因 為農民被視為只是一個促進者, 真正的農務工作是由自然 自己完成的。這種耕作方式通常強調不使用除草劑, 無機 肥料和殺蟲劑, 甚至是採取免耕(No-tillage)的方式進行。 倘與其他農耕系統相比, 實際的工作和勞動已經減少高達 $80 \%$ [3]。自然農業與有機農業不同, 因為不使用任何如蚯 蚓粪便 (Vermicompost, VC) 和農家肥料 (Farmyard Manure, FYM）等有機肥料。在日本, 福岡正信對自然進行實驗並 遵循作物繁殖的自然方式 採取不耕種、不施肥、不除草、 不用藥等四大原則, 展開了自然農業, 且實現了與化學農 業相似的產量, 但並未造成土壤侵蝕[4]。儘管如此, 仍有 利用土壤微生物以便促進土壤肥力, 因其涉及植物生長所 
需的營養物質如碳和氮的循環 [5], 可分解進入土壤的有機 物質, 並回收土壤中的營養物質。

總之, 自然農業講求順應自然、發揮在地生物固有潛 能, 並巧妙運用陰陽相生相剋之原理, 建構當地生態系統 健康平衡的友善環境。迥異於盲目使用化學肥料求得短期 迅速的效益, 這種方式為社區生態敬性穩穩地從「土地」 上扎根, 在在體現出傳統智慧「人法地, 地法天, 天法道, 道法自然」的尊重及謙卑之心。

\section{2. 領導人和集體行動}

關於影響管理公共資源的集體行動的要素, 業有不少 文獻可為指引[6-11], 並歸納四大關鍵因素為: 資源系統的 特徵(如:界定良好的邊界)、用戶群體的特徵(如:規模大小、 領導人等)、制度安排(監督、制裁規則等)以及外部環境(外 部組織的財政、非財政支持)。值得注意的是, 領導人僅是 團體特徵的重要因素之一, 然而, 領導人卻是展開集體行 動的關鍵角色, 透過積極動員及群眾熱衷參與, 以促進集 體行動。

一般而言, 領導人是否具有能力可從幾個面向觀察, 性格-個人被認為具有殊勝的特徵;行為-領導者採取行動以 利團體產生變化;技能-確認有效領導的能力; 以及, 權力關 係-領導者與追隨者之間存在的關係, 或者激勵追隨者實現 超越直接自我利益的轉型過程[12]。而Lee-Ross and Lashley （2009）指出：「領導是指領導者之間的影響關係.......追隨 者意圖真正的改變和反映其共同目標的結果」[13], 可見領 導人得以動員追隨者積極參與是集體行動展開成敗的關鍵 所在。誠如Pedler, Burgoyne and Boydell (2010) 指出, 領 導階層通常關注在「面臨重大挑戰時, 應尋找的方向和目 的。[14]」因而, 農村的領導階層需將自己置於責任制的框 架(accountability framework)中, 並儘量顧及所有的利益關 係人的權益。Dwyer and Edwards (2010)則認為, 在各級政 府, 企業和社區裡, 需要「強而有力的、堅定的和有實效 的領導階層」, 並且這些利益關係人應該發揮主動作用 $[15]$ 儘管如此, 地方領導階層仍很重要, 因為地方需要不同類 型的願景和有實效的領導階層才能實現其目標 [16]。

團體運作能否良好, 領導人是集體行動的關鍵角色, 須具有領導能力、鬼力及組織動員群體的能力。領導人擁 有豐富的經驗、專業及良好的聲望, 並積極熱衣地參與, 以促進集體行動。Glowacki and von Rueden (2015)認為, 成功的集體行動不可或缺的領導人屬性是, 相較於其他團 體成員, 其於設立目標、協調物流、努力監督、爭端解決, 或獎勵和懲罰之上, 能夠發揮更大的作用 [17]。Lobo et al.

（2016）則提醒，領導人的角色在於擔當開啟及維持集體 行動的重要中介者, 雖帶來可持續創業的解決方案, 但恐 也使社區內部出現衝突 [18] 因而, 領導人能否因勢利導, 避免衝突的滋生, 是為集體行動能否成功的關鍵所在。

\section{3. 領導人和企業家}

在集體行動的文獻裡，領導人被看作是調動資源和應 對激勵機制, 風險和機遇並創造組織的個人; 他們激發承 諾、調配資源、創造和判別機會、制定策略, 表達需求, 並影響結果[18-19]。就此而言, 領導人其實具有驅動社會
經濟發展的企業家本質。Olson(1965[1971])曾指出, 「有 想像力的企業家能夠發現或創造選擇性誘因, 以支持一個 大小適中且穩定運作的組織」。故知, 想像力或創造力的 確是企業家的主要特質[20]。

在論及共用資源管理的制度創新時, Elinor Ostrom (1965)提出「公共企業家」(public entrepreneur)的概念, 說 明其任務是:1.在不確定性之下展開集體行動方案, 2.開始 運作創新的過程，3.致力於組織的和管理活動 [21]。 Kuhnert(2001)則加以補充公共企業家精神的特質, 1. 具有 內在的動機, 2. 發現並改變偏好, 3. 在不確定下進行決策, 4.轉化願景為創新型制度設計, 5.領導與協調活動[22]。由 此可見, 領導能力是企業家創新的重要動因, 從而斷言企 業家和領導人的屬性之間存在密切的相似性並不為過。

除了從制度觀點界定企業家的類型外, Dacin et al. (2011)於定義社會創業精神(social entrepreneurship)時, 也 提出社會企業家的主要任務是提供社會問題的解決方案 以創造社會價值, 然此並不否定經濟價值, 因為經濟價值 對於社會創業企業的可持續性和創造社會價值至關重要, 有了經濟結果才能使社會企業家累積足夠的財務資源, 用 以實現其主要的使命 [23]。然而, 成功的創業精神需要有 效領導力、足夠資源和順暢流程 才能創造新的價值[24]。

綜上文獻所述, 在團體或組織中建構條件、進行決策, 關鍵的領導人或企業家, 是促成集體行動和提供集體利益 的催化劑, 因其擔當策略和運營的角色, 以調動集體行動。 無論從創新制度或創造社會價值以觀, 具有創造力的領導 人, 常能闡述願景, 提供合適的模式, 具有高績效期望以 及呈現支持性的領導行為, 更有可能追求新的機會和參與 創新[24]。

\section{3. 研究方法}

本文係以深度訪談法實地面訪霧峰農會總幹事、推廣 股股長、阿罩霧自然農召集人、崖銷班班長和副班長及班 員、社區發展協會理事長和執行長等人，7位關鍵人物為 多次訪談，10位產銷班班員則有兩次採集體方式訪談。於 2016年11月至2018年3月間執行，採不定期訪談，每次訪 談時間約一個半小時至三小時。訪談方式以半結構訪談法 為主, 即先擬定訪談大綱為主要架構, 但提問並不侷限於 預設的題目, 亦不一定會按照順序詢問, 而是根據受訪者 的回答再進一步探究, 因此訪問的問題彈性地依照受訪者 的狀況調整。問題構面分為: 各級領導人特徵、引發集體 行動的因素、障礙的克服、外部環境等面向。

由於本文係基於單一案例的研究, 故深入理解其背景 和特性, 並藉由闡述和對比理論, 以進一步了解領導人在 集體行動中的作用。而半結構化的深度訪談, 則是本文進 行分析的正式主要資料來源。次要來源則包括農會相關文 件, 會議記錄和評估報告。本文對於主要質性資料的編碼, 則是參採Fereday and Muir-Cochrane (2006)的方法, 嘗試 藉由主題分析(thematic analysis), 就重複閱讀資料並分析 其中一再湧現的主題模式加以簡要歸類, 以利後續的討論 [25]。 


\section{4. 研究個案背景}

\section{1. 霧峰農試所-孕育稻種的搖籃}

台中市位於台灣的中部, 而霧峰區則座落在該市的南 端(圖1) 其東半屬於山陵地, 有火炎山脈及九九尖峰分布; 西半部屬平原地帶, 其間有烏溪支流貫穿, 所形成的三角 洲地帶, 即霧峰的農地所在。又霧峰區的年雨量介於 1400-1665公厘, 年平均溫度約 $22.5^{\circ} \mathrm{C}$, 但全區被台三號的 公路隔成東西兩部, 其中東部因水源不足, 且多山坡地, 農業經營以種植果樹為主; 而西部因烏溪支流經過而水源 充足, 一年有兩期水稻收成。
位於該區的台灣農業試驗所(簡稱農試所), 對水稻品 種的研發, 具有舉足輕重的地位。於1992年, 由學成歸國 的郭益全博士帶領團隊積極投入稻種的研發, 該區所栽種 的香米「台農 71 號」即由農試所利用日本引入稻種「絹光」 與台灣本土種「臺稉4號」雜交配種, 歷經多年的試驗後, 成功培育出於 2000 年登記的新品種, 並在霧峰試種成功。 此種香米帶有芋頭香氣、米粒短圓飽滿、外觀晶瑩剔透, 具有耐旱、株高適中、株型佳、抗病蟲害能力強且施肥量 少等特性。為了感念郭益全博士長年的研究精神及培育出 新品種的同時卻積勞成疾猝逝, 台農 71 號香米乃由前總統 陳水扁正式命名為「益全香米」，成為國內第一個有商業 名稱的水稻及以人名命名的稻種產品[26]。

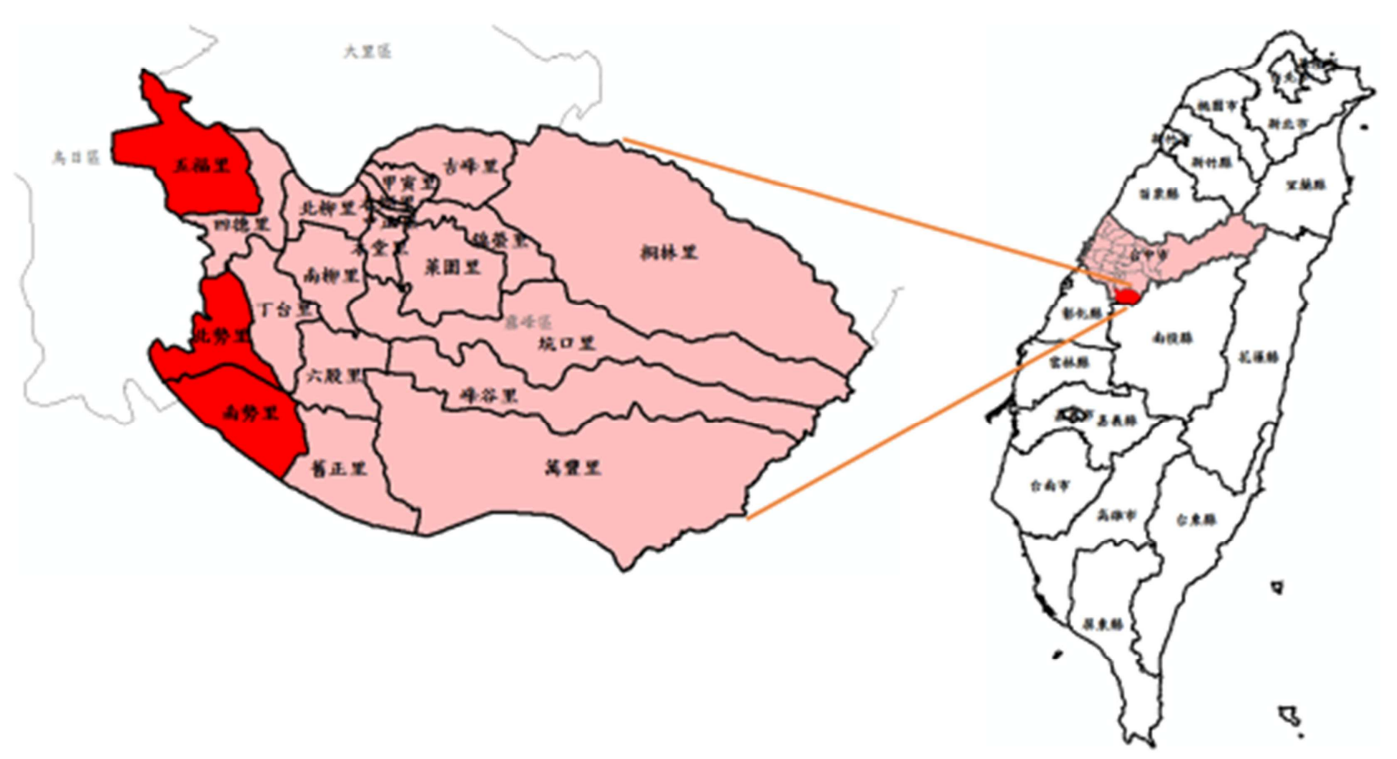

圖1 台中市霧峰區和五甲地分布於五福區、北勢區、南勢區、新六股區、丁台區的示意圖。

\section{2. 阿罩霧自然農-農法轉型的啟蒙}

談到耕種農法的轉型, 不能不提及阿罩霧自然農的影 響。阿罩霧自然農是由一群以人為本, 以達到農業永續發 展為目標的「小農」所組成; 其係以霧峰為起點, 結合南 投草屯，及台中烏日、太平、大里等地農友，為了友善土 地, 愛護自然與生態環境, 採行不使用化學農藥(必要時 會使用天然的或有機栽培可用的資材)，不使用化學肥料、 不使用殺草劑, 及必要時只施用有機肥料為基本原則的自 然(生態)農法耕作方式, 當然也包含「有機栽培」法, 甚 至也納入比「有機栽培」還嚴苛的「秀明農法」(不噴農 藥、不使用殺草劑、不施肥料)。

這是個非正式的組織, 領導人是曾任職農試所, 嗣 後於 2006年轉任科技大學教職的張有明博士; 緣因有鑑 於台灣的農田耕作大都採用「慣行農法」，使自然生態 環境遭受嚴重的破壞, 於2011年擔任舊正社區發展協會 理事長時, 就在社區推廣「自然農法」, 利用社區的簡 易溫網室種植蔬菜, 積極示範推廣自然農耕技術。繼於 2014年獲得農委會水保局核定農村再生計畫, 補助開設 「水稻自然生態農法教育講習班」, 學員共三十多位,
為遍及霧峰、國姓、大甲等地的小農和民眾，在農試所、 農藥所等專家授課與教導下, 講習課程獲得學員們熱烈 的迴響, 乃成立群組互相分享資訊和成果, 進而成立阿 罩霧自然農社群, 其近半的小農成員是曾參與講習班的 學員和老師, 目前種植水稻的有 3 位, 種植果樹的有 6 位, 生產蔬菜的有7位, 而以自然農的產品為主原料, 製作米 麵包和蔬果等加工品(例如蔬果酵素產品、果醬、蔬果乾 等等)有 5 位。在霧峰農會黃景建總幹事、農會推廣股股 長及其同仁們的支持與協助下，於 2015年7月 1 日在霧峰 農會前長廊開辦「阿罩霧自然農市集」, 先行試辦半年, 以推動社區支持型農業(community supported agriculture, CSA), 藉由在地生產、在地消費的理念, 以減少碳足跡, 推廣綠能環保, 落實節能減碳愛地球的行動[27]。

\section{3. 霧峰農會-益全香米的推廣、五甲地自然農的轉型}

2001年, 為因應台灣加入WTO對於霧峰農業的可能衝 擊, 霧峰農會乃於次年輔導成立稻米產銷班, 並推廣高品質 的「益全香米」契作, 藉以帶動霧峰地區稻作產業轉型之契 機。十多年來, 霧峰香米已在市場建立品牌與良好的口碑, 而推廣種植香米的面積, 也從最初的 7 公頃到如今近 300 公頃。 
農會黃景建總幹事素有維繫香米品質、保障稻產安全的理念, 乃以優於市場行情的價格與農民訂定契約從事栽培, 期許農 民栽種優質的香米, 更提升稻作的收益, 以創造雙贏。

容或受到阿罩霧自然農的一些小農採用秀明農法 (自 然農法的一種）的影響, 更期未來繼續提升香米品質和品 牌的形象, 於是思考試辦友善耕作稻米專區, 希冀栽種全 程不使用化學肥料 農藥與除草劑, 改變慣行農法對土地、 環境及生態的破壞, 更藉友善耕作的管理模式, 逐步喚起 社會大眾對農業、土地及生態環境的重視。黃總幹事及其 同仁乃向農民闡述自然農法的理念與作法, 鼓勵他們一起 努力轉型。起初, 農民長年習於慣行農耕, 想要配合轉型 的意願很低, 又因試辦友善耕作稻米專區, 必須距離鄰田 三米以上, 方能避免遭受鄰田噴藥影響, 故四處尋覓, 且 歷經一年的努力向農民宣導、溝通，請產銷班班長、副班 長加以動員, 並給予保證以優於市場行情的價格與農民契 約栽培, 才在五福里找到一塊面積五甲的農田, 定下生產 規模與耕作地點, 並於2015年與農民正式簽約逐步漸進採 用自然農法栽種。

\section{5. 研究個案領導人與集體行動之分析}

本文係採實地深入訪談方式, 瞭解霧峰農會總幹事及 推廣部主任、農試所研究員、稻米產銷班班長和副班長及 期班員等人, 如何在推動自然農業轉型的過程中, 擔當領 導者及追隨者角色, 展現創業精神。為求論述清晰起見, 底下將就質性資料編碼結果, 遴選三大主體, 加以分析促 成轉型的重要驅動因素。

\section{1．農會總幹事塑造願景與規劃誘因機制}

領導人通常塑造願景, 以鼓舞人心的方式向追隨者傳達 或灌輸重要目標[28]。而目標領導階層必須進行長期策略規 劃, 以便目標可以實現其發展潛力。故領導人應該能夠建立 願景並產生想法, 以便追隨者理解所涉及的挑戰, 價值觀和 時間表[29-30]。再者, 領導人具有簡明地閭述願景的能力, 才能激勵追隨者支持關鍵目標, 且在前景含糊不清或不確定 的情況下, 激發追隨者採取行動的信心[31]。

以往, 霧峰益全香米稻種的品質好, 農會實施契作價 格高, 但造成農民添加化學肥料、農藥, 以增加產量的後 果; 而農會考量近年來氣候變遷, 農業生產環境惡化, 又 逢國內稻米市場競爭激烈, 在面臨不穩定前景下, 如何維 繫農民收入, 霧峰農會責無旁殆; 身為總幹事的黃景建亦 備感壓力, 自忖長期以來令農會引以為傲的「霧峰益全香 米」還有下一個十年的光景嗎? 而農業要可持續經營的話, 自不可任令農地長期施用化肥, 否則對稻作生長與其環境 至為不利。適逢接觸農試所張博士, 獲悉其自然農業經營 理念, 黃景建經與推廣部主任詹志雲及同事們商討, 研擬

「霧峰香米 2.0 計畫」, 打算以「自然農法」取代慣行農 業, 於種稻期間不施用肥料、不用農藥, 亦不用除草劑, 以改善農業生產環境。

為了增進環境可持續性並創造社會價值, 黃總幹事有了 「自然農法」的想法後, 就請詹志雲主任與時任稻米產銷班 第九班班長黃炳南（現任農會代表）與副班長胡坤喜（現任
第九班班長) 討論如何推行。黃炳南曾在外地公司就業, 擔 任高級幹部, 能言善道, 十五年前回鄉務農, 他回憶說:

「我們總幹事有了新觀念時, 就會跟我們討論, 像是這 個友善的自然農法。一開始, 總幹事告訴我們時, 因為多年 耕種習慣的影響, 一時無法接受。後來, 經過不斷溝通, 為 了要顧好環境, 我也覺得必須要做這件事, 於是就和推廣部 的詹主任、副班長, 開始找地方, 要找出可以做隔離區的農 田，那時我們的工作就是找適合作自然農法的地方。」

除闆述理念外，黃總幹事還規劃如何提供誘因機制， 以保障農民的收益, 也規範農耕行為。他說:

「農會的任務之一，就是要維護農民的權益、保障農 民的收益, 因而要朝提高農民收入的方向來思考, 但是也 要規定田間管理該怎麼做, 且有違規處罰規定才行。」

於2015年的台農71號無毒健康香米契作合約書, 除載 明合約品種、期間、品種积苗、契作對象與面積外, 還須 善盡栽培管理之責、接受指定技術指導機關之指導, 如果 有違規定，農會不予收購、終止合約、取消契作資格。至 於收購價格, 則由農會以洷穀每百臺斤1280元收購, 並保 證依當期作香米慣行農法平均收穫量為基準保證收購量 (按14割=14百臺斤), 故換算保證價格約每分地為18000元; 但須按農會指定的時間統一插积、施肥、收割, 契作生產 稻穀數量應全數繳交農會, 否則取消契作資格。於2016 年的台農71號自然農法香米契作合約書, 則將收購價格更 動為每分地 14000 元收購, 更規定農民於栽培管理期間所 用有機質肥料、防治資材均由農會供應並統一施用, 農民 不得使用除草劑[32-33]。

經向黃總幹事查詢這兩年的收購價格、農民應負責任 有何差別, 總幹事說:

「這樣做是為了進一步保障農民收益, 而談到契約精 神, 這新舊合約都是由農會承擔產量多寡的風險, 不同的 是, 原本舊制是農友個別以自然農法管理, 而新的合約則 強調依照農會的栽培管理方式進行統一管理, 兩者之間相 較, 舊制度較易產生農友在管理上的差異, 而有品質不一 和違規的風險! 但是新制度當可避免這些問題滋生。」

\section{2. 農試所專家提供栽培管理技術與實作指導}

在集體行動展開的過程中，領導人如何善用源自於外 部環境的政府與非政府的支援與協調者的扶助, 帶領團體 成員實現共同利益, 是為成功與否的關鍵所在。因此, 如 領導人自身不具備自然農法的耕種技術, 即須尋求外部資 源一農業專家予以協助, 才能解決問題。

阿罩霧自然農的召集人張博士雖是啟發黃總幹事農法 操作的關鍵人, 然因其專長為蔬菜果樹栽培, 且已經自農試 所退休, 因而黃總幹事思考農法轉變的過程, 仍須找其他專 家給予技術指導。當年農試所郭益全博士領導的台農 71 號計 畫, 賴明信博士即是團隊成員之一。於「益全香米」育成後, 因穀粒大而飽滿, 米粒外觀優良, 加上抗病蟲害性佳, 可以 減輕施作期間藥物的使用。為使農民和消費者認識品質優良 的「益全香米」, 乃於郭博士過世後接下了研究室繼續推廣 的工作。由於「益全香米」在生長過程不需過度施肥, 一旦 氮肥施用過度容易造成倒伏, 此與農民以往施用高氮肥以獲 得高產量的習慣不同, 誤以為該品種容易倒伏而加以排斥。 
在歷經三、四年辛苦推廣，才稍微看到成果[34]。由於賴博 士是育成香米的重要推手，又是水稻栽培的專家，因而成為 技術指導的最佳人選。受到黃總幹事的請託，開始設計不噴 灑農藥的自然農法教育訓練課程。

2015年，在賴明信博士的技術指導下，終於踏出無毒 農法的第一步，開始與五福社區產銷班9位農友契作，建 立以自然農法栽培為本的香米田區。接著, 透過講習訓練 課程, 共同討論確定栽培管理的流程及執行, 更辦理到台 中市外埔區與大甲區有機水稻產銷班觀摩研習, 以學習友 善耕作的管理要點。

2016年, 霧峰農會在五福里「五甲地」的田間舉行「自 然農法」栽培觀摩會, 邀請上百位農友赴田間實地觀摩, 農民特別推崇感謝賴明信博士的盡心盡力輔導, 可謂居功 厥偉。賴博士認為農民長期種植水稻, 過度依賴資材的觀 念已經行不通, 尤其面對全球氣候的詭譎善變, 必需具有 應變的新思維。而種稻要如同人類對身體的健康管理方式 來維護管理稻米，「自然農法」兼具人與地「健康管理」 的雙重特質, 經輔導栽培成功, 證實值得採行 [35]。

\section{3. 產銷班班長與副班長動員農法轉型}

領導可視為「個體影響一群人實現共同目標的過程, 就像是領導者和追隨者之間發生交互作用的雙向事件」 [12]。不論是無毒農法還是自然農法的推廣, 都需要領導 人闡述理念以及可能的利基, 才會有農民願意相隨、確實 執行, 以達成共同的目標。對於五福里的農民而言, 霧峰 農會總幹事、推廣部主任是提供財政資源的外部領導人, 產銷班班長、副班長是其理念的追隨者; 但是, 農耕由慣 行農法轉型為自然農法, 還是得由社區的內部領導人激勵 班員追隨者, 方有具體實踐的可能。

當農會推廣部詹志雲主任向稻米產銷班第九班班長 與副班長說明推動農法轉變的想法, 並初步獲得首肯後, 便一起找到「五福社區南邊一條溪, 從那條溪一直到這邊 的大馬路, 打算選擇這個完整區塊作為自然農法的發跡 地」, 副班長畫出這個區塊後, 就由擅長溝通的班長遊說 範圍內的農民, 他說:

「我們與詹主任很認真地跟每位農民協調, 除了一個 農民不是我們的產銷班班員外，其他都是班員，平常我們 都有密切討論, 會有感情。但要改變農耕方式, 一開始還 是被揶揄頭殼壞去, 讓他們難以接受。農民對於農業生產 其實是很在意的, 每一分地生產多少稻米, 用多少農藥與 肥料, 何時放水和灑農藥或肥料, 一公斤收多少錢, 都很 清楚, 但面對不熟悉的自然農法, 又不用農藥與肥料, 產 量一定會少很多, 如此要改變慣行農法, 會讓他們很擔憂。」 副班長則說:

「沒做就什麼事都不可能發生, 就是要踏出去第一步 才行。雖然經過一段努力撮合的時間, 但幸好整合成功, 總共有9位班員加入。於是我們就從2015年開始的第一期 稻作改採自然農法, 但這一種下去, 卻遇到冷風, 運氣很 差, 一分地只有3、4割（即300 400台斤）。若不是總幹 事有決心，還是跟著合約走，真的沒辦法撐下去。」

一般而言, 慣行農法一分地收14、15割, 自然農法估 計只收到9、10割, 在霧峰農會契作收購價格的支持下,
第二期繼續以自然農法施作，卻遇到了颱風，收成受到影 響, 不過與慣行農法的9割相比, 自然農法竟還有9割, 農 作物相對損失竟然較慣行的農地少, 使得產銷班班員非常 興奮。副班長說:

「因為改採自然農法後, 水稻的根系可深入土壤中, 抓地力較強, 遇到強風暴雨倒伏率不那麼高, 一般的產量 原本就大概可達 10 割, 所以面對嚴峻的氣候變遷, 它的產 量變化反而不像慣行農法那麼大。」

至於農法的轉變，除了收入有保障之外，還有何好處？ 據班長表示:

「我們這裡自從採用自然農法耕作後, 許久不見的螢 火蟲都出現了, 田間的生態變得更豐富, 空氣也不再有刺 鼻味。田間的生物多樣性代表著生態環境的改善, 也代表 農村居民生活品質提昇。」

綜上分析, 可知促成農法轉型有三個重要驅動因素: 農會塑造願景並規劃誘因機制、農試所提供栽培技術、產 銷班領導成功動員。由此可見, 領導人是推動「組織有效 性和成功的內生發展集體行動」成敗的關鍵所在。然因農 試所研究員在本案的職能屬於技術指導專家, 於舉辦教育 訓練講習時, 扮演傳遞自然農法知識與實務操作的角色, 影響集體動員力相對較小, 因而在以下論及領導人在集體 行動的作用一節, 將探討農會與產銷班領導人為交易型或 變革型及其發揮的作用。

\section{6. 領導人在集體行動之作用}

在本文選取的個案裡，不同的組織各有其領導人，然 若沒有追隨者, 領導人將無法履行領導職責, 達成目標。 本案各組織的共同目標設定為改採自然農法, 故於展開農 法轉型的過程中, 領導階層須先設法謀求共識。一般而言, 地方的領導可能是交易型或變革型, 交易型領導是指追求 共同目標的領導者和追隨者之間的關係 $[13,29,36]$, 而 變革型領導則是試圖改變人們, 並發揮影響力使追隨者完 成超越預期的績效 [12]。本案的領導人, 在農法轉型的過 程裡, 多少交替發揮這樣的作用, 但程度有所不同, 採用 傾向的語詞, 係為強調其所發揮的作用, 茲說明如次。

\section{1. 變革型傾向領導人的經理地位}

變革型領導人意欲激發屬員並積極參與其活動, 使他們 加以轉型, 能夠表現超乎預期; 又領導人在表達對未來的共 同願景時也會積極自我轉型 充當榜樣 鼓勵接受集體目標, 設定高期望, 並為屬員的個人發展需求提供智力刺激和支持 [37-39]。這類型的領導人有如創新制度或創造社會價值的企 業家, 在創造營收過程中, 也善盡企業的社會責任。

在這次的農法轉型的集體行動裡, 黃總幹事素有改變 慣行農法朝永續農業邁進的想法, 原本和同事討論推動有 機栽培水稻方式, 然因五福社區附近的田區耕種多採慣行 農法, 要通過嚴格的查驗有其困難, 於是共商循序漸進的 方式, 由無毒農法進化到自然農法。這項變革必須商請關 鍵人物展開遊說, 並研擬配套措施, 才有辦法落實。農會 能夠做的是, 除勸說農法轉型對人地健康、環境維護有莫 大效益外, 最重要的是提供足夠的誘因機制, 以確保優良 
香米的品質。在契作合約書中, 最大的「正向誘因」為稻 穀保證收購價格, 但須謹守規範, 即: 農耕過程技術良好、 依照規定施用有機肥及防治資材、填寫生產履歷紀錄、不 使用化學肥料與農藥(含田埂除草劑)、自行管理田間灌水 與除草, 收割前至田間實地勘查並抽驗殘留毒素, 合格後 方以保證契作價格收購。至於「負向誘因」為, 如有未依 規定善盡管理栽培之責, 或不接受指定機關技術指導, 農 會不予收購、終止契約並取消資格。

要言之, 農會黃總幹事在建立誘因機制後, 也確實嚴加 執行。該機制施行迄今, 依然延續。以2017年一期作為例,
如表1所示, 自然農契作戶每分地的總收入雖較其他慣行農 作專區的總收入還低, 然因耕種過程不需噴灑化學農藥與肥 料, 支出成本也相對較低 從而純收益不致落差太大。不過, 其他兩類採慣行農法專區的生產收入看似相對較高, 但此係 表慣行農業經營狀況最好的情況下, 惟仍存有管理不易、天 災或病蟲害導致產量不穩定的風險。儘管採行自然農法的收 穫量不及慣行農法, 但生產出來的稻米品質卻受到一致的好 評, 農會也以保價收購的方式, 使農民能在無產量壓力的情 況下繼續堅持自然農法的耕作方式。

表 1 霧峰農會各種經營方式每分地稻穀收購價格(2017 年一期作)。

\begin{tabular}{llll}
\hline 成本與收益 & 稻米產銷專業區 & 其他糧商契作(專區) & 自然農契作戶 \\
\hline 總收入(元) & 20484 & 19420 & 15500 \\
支出成本(元) & 8680 & 8680 & 5050 \\
純收益(元) & 11804 & 10740 & 10450 \\
\hline
\end{tabular}

註:稻穀收入尚包含直接給付 1350 元、專區給付 150 元 資料來源:霧峰農會

表2 五甲地各期契作面積。

\begin{tabular}{lll}
\hline 年度 & 第1期 & 第2期 \\
\hline 2015 & 5.2 公頃 & 5.48 公頃 \\
2016 & 6公頃 & 7.4 公頃 \\
2017 & 16 公頃 & 32.5 公頃 \\
2018 & 38.6 公頃 & - \\
\hline
\end{tabular}

資料來源:霧峰農會

或因受到農法轉型的利基所影響, 契作耕種面積已由 原本的5甲地, 逐年擴充, 而地理區位也從五福段擴展到 南勢、北勢、新六股、丁台等其他地段(圖1), 契作面積幾 達40甲，可謂成績斐然!(見表2)

然而, 農業推廣所需經費浩繁, 除須擬具計畫爭取理 監事認同而核撥用費外，還須設法爭取外部資源。當初想 到由企業認養, 是為了使大面積自然農法栽種的風險降低, 這可透過直銷的方式以減少通路費用, 並增強農會承擔產 量減少及受災害影響的能力！於是，展開「百甲良田復育 計畫」, 邀請在地企業認養五甲米生產地, 認養數量為每 單位一分地, 每期作每分地認養金額為新台幣 38000 元, 共規劃 50 單位, 至少認養一單位。認養者可獲得水稻約定 收成量碾製成香米 2 公斤, 共 120 包, 採客製化方式製成「五 甲地米」, 以利自用或餽贈親友、客戶。認養企業的員工 可利用假日徜徉在阡陌農田, 體驗一日農夫生活並田園之 樂趣。自開辦迄今, 已有近 40 個企業參與認養, 可說是成 效卓著。

此外, 霧峰區農會為提高益全香米的附加價值, 乃 利用香米開發加工品及結合當地農特產品, 於2007年成 立酒莊, 以開創香米文化創意產業, 並派員至日本學習 香米釀造清酒技術, 以香米成功釀造出臺灣的頂級清酒。 於 2015 年推行無毒、自然農法後, 旋即改以五甲地米釀 酒, 其初霧商品即取自「阿罩霧初釀的酒香」之意, 蘊 涵感恩鄉土自然惠賜、融合地方文化及日式清酒美學韻 味, 不僅找到去化香米之路, 也能促進富含創意的農特 產業蓬勃發展。

\section{2. 交易型傾向領導人的中介地位}

交易型領導是指領導者明確表達領導者與追隨者之 間交換關係的期望的領導風格。因此, 這種領導人會傳達 具體的期望值, 並根據他們的追隨者是否達到預設目標以 提供獎勵[37-38]。如同變革型領導人, 交易型領導人也希 望所屬成員能夠承諾致力於特定目標的達成且擔負責任 [40]。在本案例中, 產銷班班長、副班長的目標是使班員 接受, 支持且參與組織的耕種改採自然農法的創意計劃; 而所謂的獎勵, 即是農會提供的誘因機制。

在農會推動自然農法耕種的伊始, 許多農民都無法接受, 時任產銷班的黃班長(今為黃代表), 告訴班員, 黃總幹事的 理念很好, 又是以當期作慣行農法平均收穫量為基準, 採保 價收購, 農民有絕對優勢, 可保障收益。然於2015年推動的 結果, 因低溫、颱風導致歉收, 也造成農會血本無歸。黃總 幹事迫於收購成本高但農產收穫量偏低的失衡宭困, 不得不 改變2016年收購價格的計算方式。於是，派兩位農會代表跟 黃班長會談收購價格, 一開始價格較低, 導致班員紛紛萌生 退意, 於是央求黃班長跟農會協商。為避免班員又重操慣行 農法, 黃代表曾向農會代表提出這樣的想法:

「這次打算修改的辦法, 必須考慮農民的基本收益, 從前採慣行農法時, 每分地利潤高則 10000 元多, 低也有 5000 元, 約略平均計算, 每分地至少要有 8000 元的收益才 行! 後來農會提高到 8500 元，加上獎勵金 250 元，共約 8750 元; 如果再將翻耕、插秧、割稻、運送、秧苗等費用加在 一起, 成本就要 5000 元, 這樣反推總收入, 至少就要是 13750 元。」

最後, 農會決定收購的價錢是每分地 14000 元, 希冀 農民繼續朝轉型自然農法邁進。儘管每分地可享有保證收 購價格, 收益相當穩當, 但農民還是盡心盡力進行田間維 護管理。黃班長說:

「有幾次秧苗的品質欠佳, 插秧過後沒多久就枯黃了, 農會雖然沒有嚴格規定要補齊, 但農民認為不能讓總幹事 漏氣, 還是再買新秧苗補插, 讓它生長齊全, 這是一種輸 人不輸陣的想法啦!」 
胡副班長(今任班長)指出, 黃代表就是農會跟班員之 間最佳的中間人, 也是溝通的橋樑:

「因為他講話有條理，有魅力，又會以身作則，我們 在一起久了, 就像親兄弟一樣, 我們信任他, 也相信總幹

事, 都是為我們設想, 他替我們去談, 都有好結果的!」

事實上, 胡副班長自小參與務農已逾五十多載, 經驗 極為豐富, 個性憼厚, 身體力行, 只要是對產銷班有利的 事, 都願意配合黃班長推行, 也會以行動力挺, 於是在勸 服班員加入自然農業經營的過程裡, 發揮相輔相成的作用, 最終促成班員相互合作, 造就了豐富的三生環境, 也厚植 了社會資本。

\section{7. 結論}

近數十年來, 慣行農業致使社會生態環境的劣質化越 趨明顯, 人們意識到這種操作模式有礙人地健康, 決意從 慣行農業轉向無毒或自然農業操作, 以使農業經營朝向可 持續性發展。然而, 農法的轉型不能只靠個人獨立行使, 還須一定區域範圍內的農民展開集體行動, 始克有成。

本文為了理解領導能力在推動自然農業中集體行動 的作用, 採用定性研究方法, 選取台灣台中市霧峰區為研 究案例, 並分析促成農法轉型的三個重要驅動因素: 農會 塑造願景並規劃誘因機制、農試所提供栽培技術、產銷班 領導成功動員。從中得到的一些研究成果是:

1. 領導者的角色是啟動和維持集體行動的必要「經理 人」與「中介人」--前者猶如霧峰農會總幹事, 為制 度和社會企業家的變革型領導人，積極參與制度設 計產生改革, 並且創造誘因分配資源, 以促成可持 續發展的機會。後者猶如產銷班班長和副班長, 為 傳遞訊息給追隨者以達預設目標的交易型領導人, 努力勸服組織成員以集體推動改採自然農法的創意 計劃。兩者對於農法轉型的啟動、推展, 有其不可 或缺的地位。

2. 領導者尋求機會解決可持續發展面臨的問題, 應對 合作和不確定性的挑戰—霧峰農會領導者為謀農法 轉型, 需要強化追隨者的觀念並尋求資源鼓勵其主 動參與, 以便農民願意努力從事自然農業生產以維 持經濟。然因採慣行農法農田毗鄰, 農民耕種習慣 難以完全改變, 如要全面推展自然農業有其困難。 何況面對氣候變遷的不確定因素, 人工除草較耗體 力, 使得產銷班的領導人必須尋求改進栽培管理方 法, 也要不斷調整動員方式, 避免追隨者意志不堅 又回歸慣行農業的老路。

3. 領導者推廣自然農業的耕地面積正迅速擴大, 將自 然農業的產品轉化為優質清酒一由於霧峰農會總幹 事運用農會內部資源和農會推廣部主任、產銷班動 員班員締造自然農業的生產佳績, 使得推廣面積逐 年擴增, 農會亦自創五甲地品牌, 也將優質米做為 釀酒材料, 製作高級香醇的清酒, 創造香米價值的 極致。以往, 是農會努力勸說推廣自然農法栽種面 積, 如今卻有更多農民主動詢問如何參與, 因而, 朝向百甲良田復育的佳績, 理當指日可待。
總之, 霧峰區自然農法的採行已算是成功的集體動員, 因為沒有任何農民違規而被取消資格, 且在轉型過程中也 沒有什麼衝突滋生, 現今的黃代表和產銷班班長、各組組 長依然扮演重要的勸說和踐行的關鍵角色, 但農會總幹事 和推廣部主任仍然戰戰兢競不敢鬆懈, 希望在翻耕蓋平、 灌溉水位和秧苗高度上做好管控, 避免雜草問題衍生管理 上的困擾。2017年5月，台灣的政府頒布「有機及友善環 境耕作補貼要點」; 嗣於2018年5月8日, 經立法院院會三 讀通過「有機農業促進法」, 同年5月30日公布, 並自公 布後一年施行。凡此或許是未來可注入外部資源的契機, 當能使農業經營達到可持續發展!

\section{致謝}

本文為台灣科技部補助《探索二十一世紀環境規劃新 典範的行動研究--農地利用、農業環境公共財供應集體行 動之研究一兼論 $\mathrm{OECD}$ 新鄉村典範在台灣的適用性(II)》 (MOST106-2621-M-004-005)的階段性成果之一。又撰寫期 間, 承蒙霧峰農會、五福社區產銷班提供資訊、接受訪談, 謹此致謝。

\section{参考文献}

[1] Colbourn P, Thornton I, Lead pollution in agricultural soils [J]. J Soil Sci 1978, 29: 513-526.

[2] Ma, LQ, Rao, GN. Chemical Fractionation of Cadmium, Copper, Nickel, and Zinc in Contaminated Soils[J]. J Environ. Qual 1997, 26: 259-264.

[3] Devarinti, SR, Natural Farming: Eco-Friendly and Sustainable? [J] Agrotechnology, 2016, 5: 147. doi:

10.4172/2168-9881.1000147,https://www.omicsonline.org/op en-access/natural-farming-ecofriendly-and-sustainable-2168-9 881-1000147.php?aid=80363\&view=mobile.

[4] Fukuoka, M., The One-Straw Revolution[M]. Rodale Press, Emmaus, 1978.

[5] Lazarovits G. Rhizobacteria for improvement of Plant Growth and Establishment[J]. HortScience 1997, 32: 188-192.

[6] Ostrom, E. Governing the Commons: The Evolution of Institutions for Collective Action[M]. Cambridge University Press. 1990.

[7] Agrawal, A. Common property institutions and sustainable governance of resources[J]. World Development, 2001, 29(10): 1649-1672.

[8] Baland, J. M. and Platteau, J. P. Halting Degradation of Natural Resources: Is There a role for Rural Communities ? [J] Oxford: Clarendon Press. 1996.

[9] Rasmussen, L., Meinzen-Dick, R. Local Organizations for Natural Resource Management: Lessons from Theoretical and Empirical Literature. IFPRI Environment and Production Technology Division Discussion Paper 11[R]. International Food Policy Research Institute, Washington, DC. 1995. 
[10] Markelova, H., Meinzen Dick, R., Hellin, J., Dohrn, S. Collective action for smallholder market access[J]. Food Policy 2009, 34 (1): 7-14.

[11] OECD. Providing Agri-Environmental Public Goods through Collection Action[M]. Paris: OECD. 2013.

[12] Northouse, P. G. Leadership: Theory and Practice (5th ed.) [M]. Thousand Oaks: Sage. 2010.

[13] Lee-Ross, D., \& Lashley, C. Entrepreneurship \& small business management in the hospitality industry[M]. Oxford: Butterworth-Heinemann. 2009.

[14] Pedler, M., Burgoyne, J., \& Boydell, T. A manager's guide to leadership: An action learning approach (2nd ed.)[M]. Berkshire: McGraw-Hill Publishing Company. 2010.

[15] Dwyer, L., \& Edwards, D.. Sustainable tourism planning. In J. J. Liburd, \& D.Edwards (Eds.), Understanding the sustainable development of tourism[M]. Oxford: Goodfellow Publishers Limited. 2010, 19-44.

[16] Richards, G., \& Palmer, R. Eventful cities: Cultural management and urban revitalisation[M]. Oxford: Butterworth-Heinemann. 2010.

[17] Glowacki L, von Rueden C. Leadership solves collective action problems in small-scale societies[J]. Phil. Trans. R. Soc. B. 2015, 370: 20150010 . http://dx.doi.org/10.1098/rstb.2015.0010.

[18] Lobo, I.D., Velez, M. \& Puerto, S.,. Leadership, entrepreneurship and collective action: A case study from the Colombian Pacific Region[J]. International Journal of the Commons. 2016, 10(2):982-1012. DOI: http://doi.org/10.18352/ijc.640.

[19] Morris, A. and S. Staggenborg. Leadership in Social Movements. In The Blackwell Companion to Social Movements[M]. In D. Snow, S. Soule, and H. Kriesi(Eds.), Oxford: Blackwell Publishing. 2004:171-96. http://dx.doi.org/10.1002/9780470999103.ch8.

[20] Olson, M. The Logic of Collective Action[M]. Cambridge, Mass.: Harvard University Press. 1965 [1971].

[21] Ostrom, E. Public Entrepreneurship: A Case Study in Ground Water Basin Management. Ph.D. Dissertation[D]. University of California-Los Angeles. 1965.

[22] Kuhnert, S., An Evolutionary Theory of Collective Action: Schumpeterian Entrepreneurship for the Common Good[J]. Constitutional Political Economy, January 2001, 12(1):13-29.

[23] Dacin, T., P. Dacin, and P. Tracey. Social Entrepreneurship: A Critique and Future Directions[J]. Organizations Science 2011, 22(5):1203-13. http://dx.doi.org/10.1287/orsc.1100.0620.

[24] Reid, S.W., A.H. Anglin, J.E. Baur, J.C. Short, M.R. Buckley, Blazing new trails or opportunity lost? Evaluating research at the intersection of leadership and entrepreneurship $[J]$. The Leadership Quarterly, 2018, 29 (1): 150-164.

[25] Fereday, J., \& Muir-Cochrane, E. Demonstrating rigor using thematic analysis: A hybridapproach of inductive and deductive coding and theme development[J]. International Journal of Qualitative Methods, 2006, 5(1): 80-92. Retrieved
[2018.03.11] from

http://www.ualberta.ca/ iiqm/backissues/5_1/pdf/fereday.pdf.

[26] 顏愛靜、林怡利、李宏文、李彥儒、辛韓根、陳錦慧、徐 雲振、黃信閔、鄭淑惠、蕭聖澄、廖國柱、謝偉仁, 農村 心能量～物豐之鄉 $[\mathrm{J}]$, 農業世界雜誌, 2017年11月, 411:51-61。

[27] 廖淑娟、蕭至邦, 推動社區產業發展策略之探討一以霧峰 區舊正社區為例 $[\mathrm{J}]$, 社區發展季刊, 2016年6月, 154: 171-182。

[28] Nanus, B. Visionary leadership: Creating a compelling sense of direction for your organization[M]. San Francisco, CA.: Jossey-Bass Inc., 1992.

[29] Burns, P. Entrepreneurship and small business[M]. Palgrave, Basingstoke, 2001.

[30] Haven-Tang, C. and Jones, E. "Local Leadership For Rural Tourism Development: A Case Study of Adventa, Monmouthshire[J]. UK" Tourism Management Perspectives, 2012(4): 28-35

[31] Berson, Y. Berson, N. Halevy, B. Shamir, M. Erez, Leading from different psychological distances: A construal-level perspective on vision communication, goal setting, and follower motivation[J]. The Leadership Quarterly, 2015, 26 (2): 143-155.

[32] 黃景建, 台農71號無毒健康香米契作合約書[Z], 2015年。

[33] 黃景建, 台農71號自然農法香米契作合約書[Z], 2016年。

[34] 台灣稻農田,稻種故事-台農71號, PayEasy平台[Z], 2015。 瀏覽日期:2018/03/18

http://www.payeasy.com.tw/taiwanrice/paddy_cultivar/paddy 71.html。

[35] 黃永順, 霧峰米採自然農法 水稻變黃金, 台灣明鏡新聞網 [Z]，2016年6月9日。http://www.webnews.tw/。

[36] Davies, A. Local leadership and rural renewal through festival fun: The case of SnowFest[M]. In C. Gibson, \& C. Connell (Eds.), Festival places: Revitalising rural Australia. Bristol: Channel View Publications. 2011: 61-73.

[37] Bass, B.M. Leadership and performance beyond expectations[M]. New York:The Free Press, 1985.

[38] Podsakoff, P. M., MacKenzie, S. B., Morrman, R. H., \&Fetter, R. Transformational leader behaviors and their effects on follower's trust in leader, satisfaction, and organizational citizenship behaviors[J]. Leadership Quarterly, 1990(1): 107-142.

[39] Yukl, G. An evaluation of conceptual weaknesses in transformational and charismatic leadership theories[J]. Leadership Quarterly, 1999(10): 285-305.

[40] Klein, H.J., Molloy, J., \& Brinsfield, C. Reconceptualizing workplace commitment to redress a stretched construct: Revisiting assumptions and removing confounds[J]. Academy of Management Review, 2012, 37: 130-151. 